STUDIA I PRACE WYDZIAŁU NAUK EKONOMICZNYCH I ZARZĄDZANIA NR 40, T. 2

DOI: $10.18276 / \operatorname{sip} .2015 .40 / 2-17$

\author{
Barbara Hadryjańska* \\ Uniwersytet Przyrodniczy w Poznaniu
}

\title{
ZRÓWNOWAŻONA PRODUKCJA W PRZEDSIĘBIORSTWACH BRANŻY MLECZARSKIEJ
}

\section{STRESZCZENIE}

W artykule przedstawiono działania prośrodowiskowe wdrażane w przedsiębiorstwach mleczarskich. Wpływają one na realizację koncepcji trwałego i zrównoważonego rozwoju na poziomie mikroekonomicznym i przyczyniają się do zrównoważenia produkcji przetworów mleczarskich. W pracy scharakteryzowano te działania produkcyjne, które poprawiają parametry środowiskowe przedsiębiorstw w zakresie gospodarki wodno-ściekowej, gospodarki odpadami oraz ochrony powietrza atmosferycznego. Dane zaprezentowane w pracy są wynikiem badań naukowych wykonanych w branży mleczarskiej na terenie całego kraju.

Słowa kluczowe: przedsiębiorstwa mleczarskie, zrównoważona produkcja, ochrona środowiska, działania prośrodowiskowe

\section{Wprowadzenie}

Koncepcja zrównoważonego rozwoju została wykreowana przez twórców raportów Klubu Rzymskiego, ale za punkt wyjścia do dyskusji na ten temat najczęściej przyjmuje się sformułowanie Komisji Brundtland, według której ${ }^{1}$ : „Trwały rozwój

*Adres e-mail: hadryjanska@up.poznan.pl.

${ }^{1}$ H. Rogall, Ekonomia zrównoważonego rozwoju. Teoria i praktyka, Wydawnictwo Zysk i S-ka, Poznań 2010, s. 31-53, 524-525. 
jest rozwojem zaspokajającym potrzeby teraźniejszości bez ryzyka, że przyszłe pokolenia nie będą mogły zaspokoić swoich potrzeb". W koncepcji trwałego i zrównoważonego rozwoju podstawowym założeniem jest integracja celów ekonomicznych, środowiskowych i społecznych. Zapewnienie realizacji tych celów wymaga jednocześnie zrównoważenia produkcji, jak i konsumpcji. Producenci powinni wykorzystywać w jak największym stopniu zasoby odnawialne, a korzystanie z zasobów nieodnawialnych powinno następować w sposób umożliwiający ich recyrkulację, nie dopuszczając do ich rozpraszania w postaci odpadów. Przedsiębiorstwa muszą inwestować w nowe technologie, które pozwolą na zminimalizowanie szkodliwego oddziaływana procesu produkcji na środowisko przyrodnicze. Natomiast zrównoważona konsumpcja powinna wiązać się z jej ograniczeniem oraz polegać na bardziej świadomym i celowym działaniu².

Aby sprostać założeniom zrównoważonego rozwoju, przedsiębiorstwa przemysłowe powinny opracować politykę środowiskową pozwalającą na uporządkowanie podejścia do ochrony środowiska przyrodniczego. Konieczne jest, aby była ona zgodna z założeniami i celami polityki ekologicznej państwa oraz UE. Zgodność ta zapewni przedsiębiorstwu prowadzenie procesu produkcji w warunkach zrównoważonych, wynikiem czego będzie produkt zrównoważony.

\section{Przedsiębiorstwa mleczarskie i ich wpływ na środowisko przyrodnicze}

Obserwowane w ostatnich dziesięcioleciach ciągłe zwiększanie antropogenicznego oddziaływania na środowisko jest przede wszystkim związane z nieustannie rosnącą liczbą ludności na Ziemi, coraz większymi jednostkowymi potrzebami konsumpcyjnymi, a także wynikającym z rozwoju technologicznego zwiększeniem możliwości produkcyjnych. Ogromna skala produkcji wyrobów jest przyczyną zużycia surowców naturalnych oraz powstawania odpadów pochodzących ze zużytych produktów lub stanowiących skutki uboczne procesu produkcyjnego ${ }^{3}$.

Zrównoważona produkcja jest terminem określającym pewien model prowadzenia działalności w zakresie przemysłu wytwórczego, którego jednym z efektów jest minimalizacja wpływu wywieranego na środowisko. Wdrożenie zasad

\footnotetext{
${ }^{2}$ R. Nowosielski, M. Spilka, A. Kania, Zarzadzanie środowiskowe i systemy zarządzania środowiskowego, Wydawnictwo Politechniki Śląskiej, Gliwice 2010, s. 50-54.

${ }^{3}$ Europa 2020. Strategia na rzecz inteligentnego i zrównoważonego rozwoju sprzyjajacego właczeniu społecznemu, http://ec.europa.eu/eu2020/pdf/1_PL_ACT_part1_v1.pdf (dostęp 15.04.2015).
} 
zrównoważonego rozwoju w działających na terenie Europy przedsiębiorstwach produkcyjnych jest jednym z priorytetów władz UE, o czym świadczy między innymi opublikowany w 2008 roku komunikat Komisji Europejskiej dotyczący planu działania na rzecz zrównoważonej konsumpcji, produkcji i polityki przemysłowej. Na jego podstawie wprowadzony został pakiet narzędzi, mających przede wszystkim stymulować popyt na proekologiczne produkty i wspierać budowanie świadomości społecznej w zakresie wpływu wyborów konsumenckich na stan środowiska naturalnego ${ }^{4}$.

Zagadnienie produkcji przyjaznej dla środowiska jest obecne również w zapisach strategii Europa 2020, wyznaczającej kierunek rozwoju Unii Europejskiej na najbliższe lata ${ }^{5}$.

Przedsiębiorstwa branży mleczarskiej, będąc wytwórcami produktów stanowiących podstawę wyżywienia ludzi, przyczyniają się do powstawania zanieczyszczeń oraz eksploatacji zasobów przyrodniczych. Dla przykładu można podać, że średnio przemysł mleczarski zużywa ok. 1\% energii elektrycznej produkowanej w Polsce ${ }^{6}$ oraz produkuje znaczne ilości odpadów opakowaniowych. Ponadto branża mleczarska jest w sektorze rolno-spożywczym branżą, która wykorzystuje na potrzeby produkcji i obsługę całej infrastruktury największe ilości wody (wg danych z 2010 r. zużywa ok. 27,6\% wody na tle całego sektora spożywczego). Wysokie zużycie wody przekłada się na znaczne ilości ścieków niosących ze sobą duży ładunek zanieczyszczeń, które muszą być odprowadzane w celu ich oczyszczenia ${ }^{7}$.

Ze względu na specyfikę surowca oraz technikę i technologię jego przetwarzania przemysł mleczarski oddziałuje przede wszystkim na jakość wód otwartych, a w mniejszym stopniu na powietrze i glebę 8 . Spośród wszystkich branż spożywczych branża mleczarska w 2010 roku wytworzyła najwięcej ścieków - 31\% ogółu ścieków przemysłu spożywczego. $Z$ tego ponad połowę stanowiły ścieki wyma-

${ }^{4}$ Ł. Adamus, Podręcznik zrównoważonej produkcji OECD, www.zb.itb.pl/informator/podrecznikzrownowazonej-produkcji-oecd (dostęp 15.04.2015).

${ }^{5}$ Ibidem.

${ }^{6}$ J. Budny, J. Turowski, Pozwolenia zintegrowane - energia elektryczna, „Przegląd Mleczarski” 2005, nr 6, s. 18-21.

${ }^{7}$ A. Kasztelan, Wpływ przemystu spożywczego na środowisko w Polsce, „Przemysł Spożywczy” 2012, t. 66, s. 12-16.

${ }^{8}$ W. Bednarski, Oddziaływanie przemystu mleczarskiego na środowisko, w: Mleczarstwo - zagadnienia wybrane, red. S. Ziajka, Wydawnictwo Art., Olsztyn 1997, s. 363-375. 
gające oczyszczenia. Warto jednak podkreślić, że spośród wszystkich branż spożywczych przemysł mleczarski charakteryzuje się najwyższym odsetkiem ścieków oczyszczanych $(99,3 \%)^{9}$.

Źródłem zanieczyszczenia powietrza przez zakłady mleczarskie są głównie kotłownie emitujące zanieczyszczenia w postaci sadzy, popiołu i związków lotnych oraz suszarnie rozpyłowe i instalacje chłodnicze. Jednak najpoważniejszym źródłem emisji zanieczyszczeń do atmosfery w przemyśle mleczarskim są kotłownie opalane węglem. Przemysł mleczarski emituje około 25\% ogólnej ilości gazów przypadających na cały sektor spożywczy i stanowi największe źródło emisji zanieczyszczeń pyłowych w tym sektorze (ponad 34\% całkowitej emisji przemysłu spożywczego w 2010 r.).

W przemyśle mleczarskim produkowane są znaczne ilości odpadów opakowaniowych. Charakterystyczne dla tej branży jest także powstawanie określonych produktów ubocznych, m.in. serwatki, osadów z wirówek i innych urządzeń, skrzepów lub kawałków serów. Ze względu na swoją wartość spożywczą odpady te są wykorzystywane jako surowce lub półprodukty w produkcji paszy dla zwierząt. Znaczna ilość odpadów powstająca podczas przetwarzania mleka jest poddawana recyklingowi lub deponowana na składowiskach. Bardzo rzadko odpady te są spalane lub kompostowane ${ }^{10}$.

\section{Zrównoważona produkcja przetworów mleczarskich}

Autorka przeprowadziła badania w obrębie polskiego przemysłu mleczarskiego dotyczące stosowanych przez zakłady produkcyjne działań prośrodowiskowych. Porównując okres bezpośrednio poprzedzający wstąpienie Polski do UE z początkiem drugiej dekady XXI wieku, można było zaobserwować zmiany zachodzące w podejściu przedsiębiorstw mleczarskich do ochrony środowiska. Zmiany te dotyczyły przede wszystkim gospodarki wodno-ściekowej, ale także gospodarki odpadami i ochrony atmosfery przed zanieczyszczeniami.

Podstawowym narzędziem badania był kwestionariusz ankietowy, który pozwolił na zrealizowanie celu, jakim była identyfikacja działań prośrodowiskowych składających się na politykę środowiskową przedsiębiorstw mleczarskich, obejmująca wszystkie komponenty środowiskowe.

\footnotetext{
${ }^{9}$ A. Kasztelan, op.cit., s. $12-16$

${ }^{10}$ Ibidem.
} 
Badania empiryczne były przeprowadzane na terenie całego kraju, a rozpoczęto je w 2010 roku i prowadzono do 2012 roku. Populację badawczą stanowiły przedsiębiorstwa przetwórstwa mleczarskiego, które zatrudniają powyżej 9 osób, czyli przedsiębiorstwa małe, średnie i duże. W 2010 roku, kiedy zaczęto realizację badań, przedsiębiorstw takich było ponad 200. Kwestionariusz ankietowy został rozesłany drogą elektroniczną oraz pocztą tradycyjną do wszystkich zakładów produkcyjnych, ale odpowiedziało na niego tylko 109 przedsiębiorstw. Wśród nich było 38 przedsiębiorstw małych (zatrudniających od 10 do 49 osób), 53 zakłady średnie (zatrudniające od 50 do 249 pracowników) oraz 18 dużych przedsiębiorstw (zatrudniających powyżej 249 osób).

Ponad $80 \%$ przedsiębiorstw poddanych ankietyzacji wdraża działania związane z ochroną środowiska, a tylko 5,5\% zakładów przemysłu mleczarskiego nie zamierza wprowadzać takich działań nawet w dalekiej przyszłości, głównie ze względów finansowych oraz niską świadomość ekologiczną kadry zarządzającej. Początek szczególnie zintensyfikowanych działań prośrodowiskowych nastąpił po 2000 roku.

Ponad $70 \%$ zakładów zajmuje się ochroną środowiska w celu dostosowania się do przepisów prawnych. Dla ponad połowy przedsiębiorstw bardzo ważny był wzrost efektywności działania oraz zmniejszenie kosztów produkcji jako skutek prowadzonej polityki środowiskowej, a dla ponad 30\% - możliwość poprawy wizerunku firmy oraz utrzymanie pozycji na rynku i spełnienie wymagań konsumentów.

W celu ograniczenia zużycia wody w procesie produkcji wytworów mleczarskich ponad $60 \%$ zakładów stosuje do mycia i spłukiwania węże wyposażone w uchwyty pistoletowe z zaworami wylotowymi (tabela 1). Ponad 50\% przedsiębiorstw używa w tym celu obiegów zamkniętych wody do chłodzenia, optymalnej konfiguracji pasteryzatora, wirówki i jednostki homogenizacyjnej oraz ogranicza w systemach CIP liczbę płukań przez zastosowanie komputerowych systemów sterowania. Prawie co drugi zakład wykorzystuje wodę z węży do mycia i czyszczenia pomieszczeń i pojazdów. 9 lat wcześniej odsetek przedsiębiorstw mleczarskich stosujących metody na ograniczenie ilości wody zużywanej w procesie produkcji był znacznie niższy. Co trzecie przedsiębiorstwo stosowało do chłodzenia obieg zamknięty wody, do mycia i spłukiwania węże wyposażone w uchwyty pistoletowe z zaworami wylotowymi, a do mycia pomieszczeń i pojazdów wodę z węży. 
Tabela 1. Sposoby ograniczania zużycia wody w przedsiębiorstwach mleczarskich w latach 2003 i 2012

\begin{tabular}{|l|c|c|c|c|}
\hline \multirow{2}{*}{$\begin{array}{c}\text { Sposoby ograniczania } \\
\text { zużycia wody }\end{array}$} & \multicolumn{2}{|c|}{2012} & \multicolumn{2}{c|}{2003} \\
\cline { 2 - 5 } & $\begin{array}{c}\text { liczba } \\
\text { przedsię- } \\
\text { biorstw }\end{array}$ & $\begin{array}{c}\text { odsetek } \\
\text { przedsię- } \\
\text { biorstw }\end{array}$ & $\begin{array}{c}\text { liczba } \\
\text { przedsię- } \\
\text { biorstw }\end{array}$ & $\begin{array}{c}\text { odsetek } \\
\text { przedsię- } \\
\text { biorstw }\end{array}$ \\
\hline $\begin{array}{l}\text { Optymalna konfiguracja i łączny projekt pastery- } \\
\text { zatora, wirówki i jednostki homogenizacyjnej }\end{array}$ & 62 & 56,9 & 30 & 27,5 \\
\hline $\begin{array}{l}\text { Stosowanie do mycia i spłukiwania węży wy- } \\
\text { posażonych w uchwyty pistoletowe z zaworami } \\
\text { wylotowymi }\end{array}$ & 71 & 65,1 & 36 & 33,0 \\
\hline $\begin{array}{l}\text { Stosowanie obiegów zamkniętych wody do chło- } \\
\text { dzenia }\end{array}$ & 62 & 56,9 & 37 & 33,9 \\
\hline $\begin{array}{l}\text { W systemach CIP (czyszczenia w miejscu) ogra- } \\
\text { niczenie liczby płukań przez zastosowanie kom- } \\
\text { puterowych systemów sterowania }\end{array}$ & 63 & 57,8 & 17 & 15,6 \\
\hline $\begin{array}{l}\text { Wykorzystanie wody z węży do mycia i czysz- } \\
\text { czenia zakładu i pojazdów }\end{array}$ & 53 & 48,6 & 39 & 35,8 \\
\hline
\end{tabular}

Źródło: badania własne.

Przedsiębiorstwa przemysłu mleczarskiego wprowadzają wiele rozwiązań, by ograniczyć ilość ścieków powstających podczas procesu produkcji (tabela 2). Jednym z nich jest pełna kontrola armatury, zaworów, kurków i uszczelek oraz ich regulacja (zawory) i wymienianie na nowe (uszczelki). $Z$ tego sposobu korzysta ponad $70 \%$ zakładów. Ponad 60\% przedsiębiorstw stosuje spawane złącza rur, właściwie przeprowadza mycie i czyszczenie urządzeń (tzn. od razu po zakończonym procesie, wodą o odpowiedniej temperaturze itp.), ściśle kontroluje wycieki mleka oraz używa przyrządów pomiarowych i sterowniczych poziomu cieczy. Około połowa zakładów mleczarskich stosuje systemy mycia pod ciśnieniem, kilkakrotnie używa, tam gdzie to możliwe, roztworów myjących, a także zapobiega spienianiu się mleka i serwatki. W 2003 roku przedsiębiorstwa branży mleczarskiej w celu ograniczenia ilości powstających ścieków stosowały głównie spawane złącza rur, pełną kontrolę armatury, zaworów, kurków i uszczelek oraz ich regulację i wymienianie na nowe, właściwie przeprowadzały mycie i czyszczenie urządzeń oraz ściśle kontrolowały wycieki mleka na linii produkcyjnej.

Pomiędzy 2003 rokiem a 2012 rokiem wyraźnie wzrósł odsetek zakładów, które wdrażają różne sposoby na ograniczenie ilości zużytej wody w procesie produkcji 
oraz ilości ścieków powstających w jego toku. Szczególnie dotyczy to wykorzystywania optymalnej konfiguracji i łącznego projektu pasteryzatora, wirówki i jednostki homogenizacyjnej, ograniczania w systemach CIP liczby płukań przez zastosowanie komputerowych systemów sterowania, a także stosowania przyrządów pomiarowych i sterowniczych poziomu cieczy oraz zbierania wszystkich wycieków.

Tabela 2. Sposoby ograniczania ilości wytwarzanych ścieków w przedsiębiorstwach mleczarskich w latach 2003 i 2012

\begin{tabular}{|c|c|c|c|c|}
\hline \multirow[b]{2}{*}{$\begin{array}{l}\text { Sposoby ograniczenia ilości } \\
\text { wytwarzanych ścieków }\end{array}$} & \multicolumn{2}{|c|}{2012} & \multicolumn{2}{|c|}{2003} \\
\hline & $\begin{array}{l}\text { liczba } \\
\text { przedsię- } \\
\text { biorstw }\end{array}$ & $\begin{array}{l}\text { odsetek } \\
\text { przedsię- } \\
\text { biorstw }\end{array}$ & $\begin{array}{l}\text { liczba } \\
\text { przedsię- } \\
\text { biorstw }\end{array}$ & $\begin{array}{l}\text { odsetek } \\
\text { przedsię- } \\
\text { biorstw }\end{array}$ \\
\hline $\begin{array}{l}\text { Pełna kontrola armatury, zaworów, kurków } \\
\text { i uszczelek oraz ich regulacja (zawory) i wymie- } \\
\text { nianie na nowe (uszczelki) }\end{array}$ & 78 & 71,6 & 59 & 54,1 \\
\hline $\begin{array}{l}\text { Właściwie przeprowadzone mycie i czyszczenie } \\
\text { urządzeń }\end{array}$ & 72 & 66,1 & 48 & 44,0 \\
\hline Stosowanie spawanych złączy rur & 75 & 68,8 & 61 & 56,0 \\
\hline Ścisła kontrola wycieków mleka & 72 & 66,1 & 48 & 44,0 \\
\hline $\begin{array}{l}\text { Stosowanie przyrządów pomiarowych i sterow- } \\
\text { niczych poziomu cieczy }\end{array}$ & 67 & 61,5 & 33 & 30,3 \\
\hline Stosowanie systemów mycia pod ciśnieniem & 64 & 58,7 & 39 & 35,8 \\
\hline Zapobieganie spienianiu się mleka i serwatki & 51 & 46,8 & 37 & 33,9 \\
\hline $\begin{array}{l}\text { Kilkakrotne stosowanie, tam gdzie to możliwe, } \\
\text { roztworów myjących }\end{array}$ & 63 & 57,8 & 35 & 32,1 \\
\hline
\end{tabular}

Źródło: badania własne.

W gospodarce odpadami przedsiębiorstwa mleczarskie szczególny nacisk kładą na minimalizowanie ilości odpadów, ich recykling, a także przeznaczanie odpadów poprodukcyjnych na paszę. Ponad połowa badanych zakładów przetwórstwa mleczarskiego deponuje odpady na składowiskach. W celu ograniczenia ilości odpadów powstających w procesie produkcji omawiane przedsiębiorstwa stosują wiele różnych rozwiązań (tabela 3). Przede wszystkim wprowadzają zmiany technologiczne (ponad $70 \%$ przedsiębiorstw) oraz modyfikacje produktowe (ponad $60 \%$ przedsiębiorstw). Ponad połowa zakładów wdraża usprawnienia wewnątrzzakładowe, a niewielki odsetek ankietowanych stosuje w tym celu opakowania wielokrotnego użyt- 
ku. W 2003 roku w celu zmniejszenia ilości odpadów przedsiębiorstwa mleczarskie koncentrowały się przede wszystkim na zmianach technologicznych.

Tabela 3. Sposoby ograniczania ilości powstających odpadów w przedsiębiorstwach mleczarskich w latach 2003 i 2012

\begin{tabular}{|l|c|c|c|c|}
\hline \multirow{2}{*}{$\begin{array}{c}\text { Działania podejmowane w celu zminimalizowa- } \\
\text { nia ilości odpadów }\end{array}$} & \multicolumn{2}{|c|}{2012} & \multicolumn{2}{c|}{2003} \\
\cline { 2 - 5 } & $\begin{array}{c}\text { liczba } \\
\text { przedsię- } \\
\text { biorstw }\end{array}$ & $\begin{array}{c}\text { odsetek } \\
\text { przedsię- } \\
\text { biorstw }\end{array}$ & $\begin{array}{c}\text { liczba } \\
\text { przedsię- } \\
\text { biorstw }\end{array}$ & $\begin{array}{c}\text { odsetek } \\
\text { przedsię- } \\
\text { biorstw }\end{array}$ \\
\hline Modyfikacja produktów & 69 & 63,3 & 24 & 22,0 \\
\hline Modyfikacja technologii & 83 & 76,1 & 54 & 49,5 \\
\hline Stosowanie opakowań wielokrotnego użytku & 26 & 23,9 & 15 & 13,8 \\
\hline Usprawnienia gospodarki wewnątrzzakładowej & 64 & 58,7 & 43 & 39,4 \\
\hline $\begin{array}{l}\text { Zmniejszenie ilości serwatki i ścinków sera od- } \\
\text { prowadzanych do ścieków }\end{array}$ & 44 & 40,4 & 16 & 14,7 \\
\hline
\end{tabular}

Źródło: badania własne.

Tabela 4. Sposoby ograniczania emisji zanieczyszczeń do atmosfery powstających w przedsiębiorstwach mleczarskich w latach 2003 i 2012

\begin{tabular}{|l|c|c|c|c|}
\hline \multirow{2}{*}{$\begin{array}{c}\text { Sposoby ograniczenia emisji } \\
\text { zanieczyszczeń do atmosfery }\end{array}$} & $\begin{array}{c}\text { liczba } \\
\text { przedsię- } \\
\text { biorstw }\end{array}$ & $\begin{array}{c}\text { odsetek } \\
\text { przedsię- } \\
\text { biorstw }\end{array}$ & $\begin{array}{c}\text { liczba } \\
\text { przedsię- } \\
\text { biorstw }\end{array}$ & $\begin{array}{c}\text { odsetek } \\
\text { przedsię- } \\
\text { biorstw }\end{array}$ \\
\cline { 2 - 5 } Ograniczenie pyłów poprzez filtry cyklonowe & 80 & 73,4 & 65 & 59,6 \\
\hline Przechodzenie na opalanie gazem & 48 & 44,0 & 102 & 93,6 \\
\hline $\begin{array}{l}\text { Stała konserwacja potencjalnych źródeł emisji } \\
\text { niezorganizowanych (z uszczelek sprężarek, } \\
\text { zaworów itp.) }\end{array}$ & 60 & 55,0 & 74 & 67,9 \\
\hline $\begin{array}{l}\text { Stosowanie paliw niskokalorycznych (ogranicze- } \\
\text { nie SO } \text { S }_{2} \text { ) }\end{array}$ & 82 & 75,2 & 78 & 71,6 \\
\hline $\begin{array}{l}\text { Stosowanie systemów wychwytujących (okapy, } \\
\text { systemy osłon) w celu ograniczenia emisji punk- } \\
\text { towych }\end{array}$ & 18 & 16,5 & 93 & 85,3 \\
\hline $\begin{array}{l}\text { Zastosowanie nowoczesnych technologii spala- } \\
\text { nia, np. złoża fluidalne (ograniczenie } \mathrm{SO}_{2} \text { ) }\end{array}$ & 51 & 46,8 & 64 & 58,7 \\
\hline $\begin{array}{l}\text { Zastosowanie w amoniakalnych systemach } \\
\text { chłodniczych programu wykrywania i napraw } \\
\text { przecieków }\end{array}$ & 45 & 41,3 & 62 & 56,9 \\
\hline
\end{tabular}

Źródło: badania własne. 
Zakłady mleczarskie podejmują wiele działan ograniczających emisje zanieczyszczeń do atmosfery (tabela 4). Ponad $70 \%$ z nich stosuje w tym celu filtry cyklonowe oraz paliwa niskokaloryczne, aby ograniczyć emisje dwutlenku siarki. 55\% ankietowanych zakładów wskazało na stałą konserwację potencjalnych źródeł emisji niezorganizowanych jako na podstawowe działanie w ramach ograniczania emisji do atmosfery. W 2003 roku prawie wszystkie przedsiębiorstwa w tym celu przeszło na opalanie gazowe, a ponad $80 \%$, aby zmniejszyć emisje punktowe, stosowało systemy wychwytujące w postaci np. okapów.

\section{Podsumowanie}

Według badań empirycznych przeprowadzonych przez autorkę, większość polskich przedsiębiorstw mleczarskich wdraża działania prośrodowiskowe. Tylko nieliczne - głównie z powodów finansowych - nie wprowadzają takich działań. Przedsiębiorstwa, które opracowują politykę środowiskową, kierują się głównie względami ustawodawczymi oraz widzą w tym szansę na poprawę wydajności produkcji oraz wzrost efektywności działania. Priorytetem dla przedsiębiorstw mleczarskich jest redukcja ładunku zanieczyszczeń ścieków, ponieważ ze względu na specyfikę surowca przemysł mleczarski oddziałuje przede wszystkim na jakość zasobów wodnych.

Autorka porównując okres bezpośrednio poprzedzający wstąpienie Polski do UE z początkiem drugiej dekady XXI wieku, była w stanie zaobserwować zmiany zachodzące $w$ podejściu przedsiębiorstw mleczarskich do ochrony środowiska. Zakłady te zwiększyły ekologiczną świadomość swoich pracowników oraz zredukowały ilość surowców potrzebnych do procesu produkcji. Ponadto większość przedsiębiorstw zainstalowała filtry redukujące zanieczyszczenia do atmosfery oraz wprowadziła opalanie gazowe.

Ochrona środowiska w przemyśle mleczarskim pomiędzy 2003 rokiem a 2012 rokiem uległa intensyfikacji, a kadra zarządzająca stała się bardziej świadoma, że takie działania, oprócz efektów ekologicznych, mogą przynieść wymierne korzyści ekonomiczne. Przedsiębiorstwa mleczarskie coraz rzadziej kierują się w ochronie środowiska jedynie względami legislacyjnymi i potrafią wykorzystać politykę środowiskową, aby zmniejszyć koszty produkcji i poprawić wizerunek przedsiębiorstwa.

Najbardziej pozytywne zmiany w ochronie środowiska w przemyśle mleczarskim zaszły w gospodarce wodno-ściekowej, a najmniej znaczące są te związane 
z ochroną atmosfery. W gospodarce wodno-ściekowej zakłady mleczarskie koncentrują się na zmniejszaniu ilości wody wykorzystywanej w procesie produkcji oraz na ograniczaniu ilości ścieków.

Podejmowane działania związane z ochroną środowiska w przedsiębiorstwach mleczarskich są dowodem na to, że zakłady te realizują założenia zrównoważonego rozwoju, a zwłaszcza jego aspekt ekonomiczny i środowiskowy. Wprowadzając sposoby na oszczędzanie wody oraz minimalizując ilość ścieków, odpadów oraz zanieczyszczeń emitowanych do atmosfery, przedsiębiorstwa poprawiają parametry środowiskowe procesu produkcji, jednocześnie korzystnie wpływając na swoją sytuację ekonomiczną.

\title{
Literatura
}

Adamus Ł., Podręcznik zrównoważonej produkcji OECD, www.zb.itb.pl/informator/ podrecznik-zrownowazonej-produkcji-oecd (dostęp 15.04.2015).

Budny J., Turowski J., Pozwolenia zintegrowane - energia elektryczna, „Przegląd Mleczarski” $2005, \mathrm{nr} 6$.

Bednarski W., Oddzialywanie przemystu mleczarskiego na środowisko, w: Mleczarstwo zagadnienia wybrane, red. S. Ziajka, Wydawnictwo Art., Olsztyn 1997.

Europa 2020. Strategia na rzecz inteligentnego i zrównoważonego rozwoju sprzyjającego właczeniu społecznemu, http://ec.europa.eu/eu2020/pdf/1_PL_ACT_part1_v1.pdf (dostęp 15.04.2015).

Kasztelan A., Wplyw przemyshu spożywczego na środowisko w Polsce, „Przemysł Spożywczy” 2012, t. 66.

Nowosielski R., Spilka M., Kania A., Zarzadzanie środowiskowe i systemy zarządzania środowiskowego, Wydawnictwo Politechniki Śląskiej, Gliwice 2010.

Rogall H., Ekonomia zrównoważonego rozwoju. Teoria i praktyka, Wydawnictwo Zysk i S-ka, Poznań 2010.

\section{SUSTAINABLE PRODUCTION IN COMPANIES OF DAIRY INDUSTRY}

\begin{abstract}
The article presents the environmental actions, which are implemented in the dairy enterprises. They affect the implementation of the sustainable development concept at the
\end{abstract}


microeconomic level and contribute to the sustainable production of dairy products. Author characterized by the production activities that improve the environmental performance of companies in the field of water and wastewater, waste management and air protection. The data presented in the article are the result of research carried out in the dairy industry throughout the country.

Translated by Barbara Hadryjańska

Keywords: dairy companies, sustainable production, environmental protection, environmental activities

JEL code: D210 
